\title{
Problems With the Application of E-government in Turkey: The Kars Pilot*
}

\author{
Haydar Efe, Sebahattin Y1ldiz \\ Kafkas University, Kars, Turkey
}

\begin{abstract}
This research aims to highlight problems encountered in the application of e-government in Turkey, including findings from the Kars Pilot Project. It also examines public administration authorities, the general public's knowledge of technology, and the practise of e-government, together with interested parties in all of these. To ensure quality of data, research methods included a questionnaire and also benefitted from secondary data. The leaders of 12 public administration authorities contributed to data collection. Within the conclusions of this work it will be seen that the pilot project in Kars would seem to have suffered from a surfeit of problems, albeit the majority of them temporary; and the work also focuses on other issues outside the Kars experience. In particular it would seem that there are issues concerning the underlying legal framework; weaknesses in the technology and in websites; users lack appropriate knowledge and there are insufficient specialist employees; weaknesses in the reliability of the systems and problems with costs were also revealed. At the same time weaknesses were encountered within the population in terms of ability to access pass-worded e-government and low levels of telephone and internet connectivity.
\end{abstract}

Keywords: e-government, application, password, Turkey, Kars

\section{Introduction}

Electronic government (e-government) is stated to be the presentation of public services in an electronic format. In all developed countries which have implemented e-government, it is claimed that it leads to greater take-up of public services and associated data collection, which in turn results in higher levels of bill payment and a strengthening of democracy. In this context Turkey would seem to have been somewhat left behind.

Initially all public authorities should have embraced the practise of e-government in concert, however, some bodies began independent projects, apparently still with the aim of e-government implementation, but actually with objectives that did not fit with those of the overall project, which resulted in an inability to share activities, and led to wasteful use of labour and resources.

Implementing e-government in an active fashion within public authorities and associations is vital, in that

\footnotetext{
* Acknowledgement: This article was expanded version of one presented to the 9th International Conference on Knowledge Economy \& Management held in Bosnia \& Herzegovina in 2011 and published within CD of the conference proceedings.

Haydar Efe, Ph.D., Asistant Professor, Department of Public Management, Kafkas University.

Sebahattin Y1ldz, Ph.D., Asistant Professor, Department of Business Administration, Kafkas University.

Correspondence concerning this article should be addressed to Sebahattin Yıldız, Kafkas University, Department of Business Administration, Kars, 36100, Turkey. E-mail: seyildiz@kafkas.edu.tr.
} 
piloting public services will lead to many problems being resolved. However, within the early stages of introducing the new e-government practises in Turkey, there were clearly fundamental flaws. This research presents problems which arose in the early application of e-government together with actions taken to resolve them, reports the results of the Kars e-government pilot, examines problems experienced by some public authorities and presents possible solutions.

\section{Background}

\section{Concept of E-government}

In its simplest, narrowest definition, the concept of e-government allows the general public to access public services utilising knowledge and communications technology (Sahin, 2007, p. 164). In the context of e-government, the actual government uses communications technology widely within its own internal operations and services (Ozcivelek, 2009). E-government has also been defined as: "the government offering the general public access to mandatory operations and services within an electronic management and communications environment which functions as a seamless, uninterrupted, secure system" (Retrieved from http://www.taek.gov.tr). The Turkish government set up a portal accessible from its website www.turkiye.gov.tr called "e-government gateway" to facilitate the public's usage of all services in an electronic environment. These services include access to information under various headings: birth, military service, career opportunities, employment advertisements, family services and social security operations amongst others, together with information services such as: integrated electronic services; payments management; shortcuts to public authorities and organisations; current news and announcements; messages from official bodies to the general public; and the sharing of knowledge and documentation between different public departments (Retrieved from http://www.turkiye.gov.tr).

The establishment, leadership and management of the e-government gateway was underpinned by a decision taken by the Council of Ministers on 24th March 2006 and numbered 2006/10316 which was then signed by the Prime Minister and given to the Ministry of Communications as the responsible body. The decision was published in the 26255 numbered Official Gazette on 10th August 2006, and was the subject of a Prime Minister's Circular number 2006/22, stating that public services would be made available in an electronic format, via a shared platform and to ensure public interest the work would be carried out swiftly, efficiently and utilising appropriate integrated standards; any necessary legislation would be put in place and the whole would be coordinated by the Ministry of Communications, involve all public authorities and also have the active participation of the Turksat Satellite News, Cable and TV Company (Retrieved from http://www.turkiye.gov.tr).

The increase in internet usage amongst the populace, coupled with the private sector's successful adoption of e-business models, would seem to have created a pressure on leaders of public authorities to deliver their services electronically to the public, a pressure which continued. In the context of e-government, it can be seen that concern for managerial and practical aspects (for example quality standards, strategic directions, user administration, etc.), which had already been addressed by the private sector in their "e-work" and "e-business" initiatives, was now transferred to the public sector leadership (Moon, 2002, p. 425).

\section{Objectives of E-government}

At a time when developments in management and information technology take place at an almost 
unbelievable pace, governments want their public services to benefit from these developments, in particular to use the internet and computers as a vehicle for presentation of public services, thus reducing reliance on old style bureaucracy and aiming to give the public access to interactive services in a data rich environment. These aims can be further broken down into the need to speed up public administration, to cut costs, to deliver democracy to all users, provide transparency, reduce old style bureaucracy, increase productivity and data collection, offer streamlined services and an active role in the process to all users (Celikkol, 2008, p. 27).

At the same time e-government would be expected to meet its stated aims and address all the practical concerns around achievement of reduced costs, control of reduction in paperwork, increase in transparency (effectively the government becoming more accountable to its users), quality of services, public services available 24 hours per day without interruption, a rise in the number of users, a retreat from old style bureaucracy, all based on smooth, fast electronic communication (Evren, 2004). The underpinning objective of increasing the capacity of information services, facilitating rapid decision-making and creating a government that responds quickly to needs had to be embedded within the leadership (Henden \& Henden, 2005, p. 50). E-government projects would aim to give the population ease of access via an interactive route to quality, fast, streamlined and secure public services (Retrieved from http://www.turkiye.gov.tr).

As in many other countries around the world, in pursuing these aims of increasing usage of public services, whilst at the same time achieving a reduction in cost, Turkey began to spawn more and more projects. The range of methods for delivering reliable internet connection, and using existing interconnected networks, would seem to imply that information can be accessed from any place. This would allow the public authorities and organisations to abandon old methods of delivering the same information and then repeatedly returning it to storage, in favour of becoming information centres. From these the users could obtain, within an official framework, reliable and complete information, comprehensive data would be collected, and decisions could be taken on the basis of correct information which would lead to faster, better decisions (Retrieved from http://www.bilgitoplumu.gov.tr).

To summarise, from the government's point of view the expectations of e-government would seem to be that it delivers public services to the population, removing barriers between the general public and its leaders, gives the users open access to public information, builds in speed and reliability of public services, encourages cooperation between public bodies by use of shared electronic management systems, reduces costs by reliance on machines rather than people, and reduces dependency on paper-based systems.

At this stage of embedding the concept of public services becoming available electronically, great emphasis was placed upon "understanding the government gateway" and "an intelligent government portal" with the prospect of everyone benefitting from using the new technology, to the point where it would seem that existing services were of a poorer quality.

\section{Contrast Between Traditional Government and E-government}

The classic view of government services is one of the general public trying to scale a bureaucratic mountain. The simplest procedure would seem to have been made more complex by those entrusted to deliver, to the point at which results can only achieved by the employment of even more personnel and public servants. Even the simplest transaction requires endless form filling and collecting of signatures, hence the process can take months 
to complete (Yildirir \& Karakurt, 2004). The classic (bureaucratic) delivery of public services is heavily reliant on paperwork, which mitigates against the individual and results in continuously increasing costs for those charged with delivery. The practise of e-government can overcome this and associated issues. Table 1 lists common beliefs in the concept of both traditional government and e-government (Uckan, 2003, p. 47).

Table 1

Traditional Government and E-government Development

\begin{tabular}{|l|l|}
\hline Traditional government & E-government \\
\hline Passive population & Active population-customers \\
\hline Paper-based operations & Electronic operations \\
\hline Layered structure (hierarchy) & Flat structure (coordination) \\
\hline Top down leadership & Bottom up customer led \\
\hline Labour heavy & Centralised automated systems \\
\hline Generic help from employees & Individualised help/specialist support \\
\hline People-based audit mechanisms & Automatic robust data audit \\
\hline Payment by cash/cheques & Electronic funds transfer (EFT) \\
\hline 'One for all' services & Individualised/customised services \\
\hline Departmentalised/fragmented services & Holistic/seamless services \\
\hline High management costs & Low management costs \\
\hline Growth unrelated to data & Data-based development \\
\hline One-directional management & Interactive \\
\hline Subjective relationships & Customer relationships \\
\hline Closed government & Open government \\
\hline
\end{tabular}

Note. Source: Uckan, O. (2003). E-government, e-democracy and Turkey, strategy and policies for reconstruction of public management-I, Literatur Publishing, Istanbul, Turkey.

\section{E-government Application in Turkey}

It can be said that the application of e-government is not merely confined to the developed world, there are developing countries who place great importance on its existence. However, it is possible that there are discrepancies with the aims of e-government between developed and developing nations. An example of this could be, say, an African country that sets up e-government with the aim of misusing authority, in the west it is possible that governments'/provinces' adoption of e-government could result in rivalry between interested parties, and all of this could be concealed beneath the governments' stated aim of giving the people access to the latest technology; it is possible to utilise e-government in a range of different ways (Demirel, 2006, p. 101)

As it can be seen from Table 2 compiled by the United Nations in 2010 following global research, Turkey lies in 69th place. In effect Turkey lies just within the upper half of the rankings.

In Turkey each public body wanted to be seen to be implementing their own e-government project. Examples include: "Official gazette information system"; the Permanent Undersecretary to the State Planning Organisation's "E-turn for Turkey project"; the Permanent Undersecretary to the Customs' "Computerised customs operations"; the Permanent Undersecretary for External Trade's "E-business knowledge pool, a portal for e-business information and working partnerships"; the Association of Capital Markets' proposed "Capital market information system project"; the Institute of Turkish Standards (TSE) "TSE quality information project"; the Turkish Council for Science and Technology (TUBITAK) announced "Information system for researchers 
(ARBIS)"; the Central Bank's "Electronic Fund Transfer System (EFS)"; the Ministry of Justice's "National Judgement Network Project (UYAP)"; the General Directorate of Security's "Mobile Electronic Systems Integration (MOBESE)"; the Ministry of Education (MEB) offered "Comprehensive Information Management System (MEBSIS)"; the General Director of the Land Registry's "TAPUNET" (the Turkish word for a land/property deed is a "tapu"); the Ministry of Health's "Patient Tracking System"; KOSGEB, an official organisation which provides support for small to medium-sized enterprises proposed "KOBINET"; and Turk Telecom's "E-government gateway" outlined above (DPT, 2005). Two others would seem worthy of inclusion here: the Central Office of Population wanted an electronic management system they termed "MERNIS"; and the tax office proposed their own automation project to result in more efficient tax collection and be known as "VEDOP"

Table 2

Top 10 Countries and Turkey in E-government Development

\begin{tabular}{lll}
\hline Rank & Country & E-government development index value \\
\hline 1 & Republic of Korea & 0.8785 \\
2 & United States & 0.8510 \\
3 & Canada & 0.8448 \\
4 & United Kingdom & 0.8147 \\
5 & Netherlands & 0.8097 \\
6 & Norway & 0.8020 \\
7 & Denmark & 0.7872 \\
8 & Australia & 0.7863 \\
9 & Spain & 0.7516 \\
10 & France & 0.7510 \\
69 & Turkey & 0.4780 \\
& World average & 0.4406 \\
\hline
\end{tabular}

Note. Source: The United Nations e-government survey (2010).

If we look for one successful application from within all of the above it would be UYAP, which was based on existing models in other countries. This project was designed to lighten the burden of legal decision-making, and when fully operational would mean all court proceedings took place in an electronic environment, written applications to the court could be sent electronically, notaries public would operate digitally and all property transactions would be registered on the internet (Gocen \& others, 2011).

Work carried out under the DPT's "E-government project and applications, September 2005" provides an example of actual e-government applications in Turkey. This project examined the websites of different public bodies and then ranked them according to the level of electronic service they offered. The rankings were: (1) "information available on-line" for those bodies which merely offered access to information; (2) "documents can be downloaded from website" for authorities from whose websites forms, reports, etc., could be printed; (3) "messages will be sent via internet to applicants" for parties willing to deal with queries via e-mail; and (4) "everything handled via internet including payments" for bodies able to manage all transactions electronically. This exercise would seem to have created interesting parameters for e-government (Retrieved from http://www.bilgitoplumu.gov.tr).

Turk Telecom's “e-government gateway" project promised to give the public information briefings, integrated electronic services, payment of bills, shortcuts to public organisations and associations, information and announcements of current affairs, messages from public bodies would be sent to members of the general 
public, and it would offer information and document sharing opportunities for all public bodies (Retrieved from http://www.turkiye.gov.tr). It would be the only public service access needed by the population and lead to data sharing between the various public authorities, and with the underpinning management structures in place the "E-government Gateway Project" was launched in 2005.

\section{E-government Applications and Problems Encountered}

For public authorities to gain maximum benefit from their services being available via information and management technology, it is vital that working practise within these authorities be redesigned to enable personnel to work in a more active and accountable fashion (Acar \& Kuvaş, 2008). In an e-government system a central spine must be created from which users can reach information in all directions. This spine will connect central administrative units to their local equivalents, and allow users to connect to any location as well as to relevant third party sites (Ince, 2001).

To offer public services electronically the necessary technologies are the internet, on-line services and e-mail in that order. Users of e-government services may carry out a range of functions facilitating aspects of their daily life (ticket reservations), to seeking direction from a remote location (an electronic form may be filled out) and taking part in political acts (voting or completing questionnaires) (Demirel, 2006, p. 91). It is possible to delineate the factors required for e-government applications under four headings: telecommunications infrastructure; appropriate legislation; capital funds; public authorities using information technology (Ulusoy \& Karakurt, 2002, pp. 139-140). In preparing the ground for e-government applications the first steps should be to address the legal basis, the technological foundation, people, funders and services along with security and privacy: all of these are critical success factors (Arifoğlu \& others, 2002, p. 39).

Problems encountered in e-government applications include legal problems, administrative problems, technological issues and security of data problems, amongst others (Celikkol, 2008, p. 44). Obstacles which may be encountered when establishing e-government include legal parameters, budget issues, internet infrastructure and technological capability of personnel (DPT, 2007, p. 35). E-government applications require commitment to keeping up with technological change, universal internet access at equal speed, and users and providers of services with sufficient technological skill (Ozcivelek, 2009).

Nowadays the people want and expect public services to be more dynamic, faster, more open and honest, and to cost less to run. In utilising the opportunities made available by technology, the e-government project brings change to the agenda of public authorities and organisations used to functioning in a culture of working to established routines. It is crucial that information is shared within and between public bodies and work processes are redesigned (DPT, 2005). It can be said that the largest barriers to the implementation of e-government are "bureaucratic resistance, personnel training and consistency issues, sources of funding and weaknesses in the technological infrastructure".

In 2009 the Prime Minister's office issued an "E-government and the Information Community Projected Act" in draft format which contained 35 clauses and a further eight proposed clauses (Basbakanlik, 2009; Retrieved from http://akgul.bilkent.edu.tr/e-devlet/taslak.pdf). This has not yet been signed into the legislation and should be addressed as a matter of urgency. At the moment the e-government system has no legal foundation whatsoever. 
It has to be said that within this draft law could be found all the public authorities and organisations, together with the information community, that would work together to implement e-government, along with the provinces in which it would be piloted. It was stated that there must be compliance with basic individual rights and freedoms within any delivery of public services, individual's personal data must be protected and computer security guaranteed, the focus must be on the individual citizen. In transferring their work to an electronic environment the public bodies would increase the rate at which work is accomplished and new routines would be imposed as required. As owners of data the public authorities and organisations would take responsibility for the security of that data. Data sharing between public bodies would be open, on a need to know basis and would not require any formal request. Only data necessary for service delivery should be collected and be available for sharing and that in accordance with the existing laws of the land. Service users must be confident that information relating to their usage is properly managed during the period of their involvement. E-government services should be made available to mobile devices where appropriate. From the users' standpoint e-government services should be easily accessible, and seen to be delivered to the satisfaction of the user in an orderly fashion. Initial barriers to this development should be overcome by all involved working with the information community to ensure maximum levels of service. Provinces involved in these preparations and applications should have regard to the necessity for speeding up decision-making, for transparency and the need for payment of accounts. Users must be made aware that payments associated with traditional public services are now to be made for e-government services. Wherever possible sensitivity should be shown to environmental concerns in products used in association with information and management technology. Appropriate measures will be taken to ensure personnel in public bodies can utilise information and management technology from remote locations. Citizens and the business world should see that e-government applications lead to lowered administrative and capital costs, resulting in greater possibilities for trade and investment. Public authorities and organisations should agree to deliver e-government projects within time constraints, to agreed budgets and in line with the original concept.

\section{Research Design}

The main aim of the research was to establish at what level the e-government applications being piloted by public authorities in the provincial capital of Kars were satisfactory, in terms of technological bases, what problems had been encountered and which services were actually functioning. Alongside this the numbers of people in the province of Kars with e-government passwords, together with internet and telephone connectivity was analysed. All aspects of the research focused on quality. Data was collected by means of a questionnaire. We benefitted from re-using the questionnaire devised by Sahin (2007) for his work on "E-municipality Applications and the Konya Pilot". The questionnaires were distributed to all public authorities and organisations from the office of the Governor of Kars. Questionnaires were completed by Heads of Department and responses were received from twelve public bodies: Post Office, Turkish National Employment Agency, Education Authority, Chief Prosecutor's Office, Health Directorate, Land Registry, Directorate of Surveying, Kars Municipal Council, Directorate of Revenue, Directorate of Finance, Public Works' office, Directorate of Housing and Provincial Directorate of Agriculture. Frequency analysis was applied to all completed questionnaires. In addition interviews were conducted with personnel from Turk Telecom to cover issues arising from pass-worded e-government together with telephone and internet connectivity, and secondary data was thus collected. 


\section{Research Results}

\section{The First Side of the Coin: The Level at Which Public Authorities in Kars Use Technology and Its Weaknesses}

Set out below are responses to the questionnaire which produced somewhat startling results. The public bodies to which the questionnaire was administered employ a total of 1,278 personnel, for whom the number of available computers is 726 . In other words a mere $56 \%$ of public servants in Kars have access to a computer. Furthermore, of these 726 machines only 522 are connected to the internet. Thus of the available computers within Kars' public services only $71 \%$ have internet connectivity.

Of the total personnel of 1,278 only 644 claimed that they could use a computer. Thus the percentage of public servants in Kars who can use a computer is $50 \%$. However, only 522 people from the total of 1,278 actually have the use of an internet-enabled computer at work. This means that only $40 \%$ of the public servants in Kars can work with the internet.

Seventy five percent of respondents thought their computer skills were "weak or only partly developed"; with the other $25 \%$ claiming skill levels from satisfactory to high levels. These results would seem to show that computer skills amongst the relevant personnel in Kars, are insufficient to ensure a successful application of e-government.

Those personnel using computers claim to be competent in "word processing, producing reports, extracting data, using a range of packages, using the internet, preparing tables, graphics and presentations". Of the twelve organisations that took part in the survey only eight (66\%) had their own web site addresses; the other four (34\%) had no web address. They were forced to use the address of the central headquarters of their organisations.

In response to the question "Are you given sufficient subsidy to raise your level of computer skills?", 33\% replied "No" with 67\% saying "Yes". It would seem the organisations involved need to revisit the issue of subsidies for personnel in this context.

The question "Does your website have links to other sites?" produced 100\% positive response. The question "Can users of the internet (general public or personnel in public authorities) easily ask questions, make requests or submit complaints related to your organisation via the internet?" gained a 91\% "Yes" response.

"Is there a written instruction or a standard concerning the amount of time within which any communication from the public: request, question or complaint; must receive a response?" was asked and received 33\% "No" and $67 \%$ "Yes" responses. This would seem to imply some public bodies need to produce such regulations/standards. The question "are the computer packages used in your workplace fit for purpose?" produced 25\% "No" and $75 \%$ "Yes" answers.

"In your workplace is the information on the hard drives regularly backed up?" resulted in 25\% "No" and 75\% "Yes" responses. "Do applications/requests received via the internet have to be followed up in writing?" received 58\% "No", and 42\% "Yes" answers.

The question "Can users of your website easily access information via the internet?" was given $100 \%$ positive response. However, the question "Do users of your website need a password to send or receive information?" produced a 50\% "No" and 50\% "Yes" response. 
"When setting up your website did you have professional help from outside your organisation?" produced responses from eight of the organisations. Of these only two (25\%) said "Yes" whilst the other six (75\%) said "No". The next question "Are you using professional help to improve your website?" met with $100 \%$ "No" answer.

"Are there any trained computer operatives in your workforce?" received 58\% "No" and 42\% "Yes" replies. "Are you offered courses on computer and internet usage and, if so, are the courses adequate?" revealed 50\% negative responses, $17 \%$ positive with the proviso that the courses were inadequate, and only $33 \%$ full "Yes" answers.

In answer to the question "How often do you refresh your web address?" $42 \%$ of respondents said "Daily", a further $42 \%$ replied "That is done by our headquarters' and $16 \%$ said "Only when necessary". "Does your organisation have an e-mail address?" received $83 \%$ "Yes" and 17\% "No" responses. One of these organisations was actually using an individual's personal e-mail address rather than that of their central office. This should clearly not be taking place when transactions involving members of the public are to take place in an orderly, objective fashion.

"How is your organisation connected to the internet?" revealed 75\% using ADSL, 17\% using a satellite connection and the remaining $8 \%$ reliant on dial-up internet connectivity. In response to the question "How many hours each day does the connection work?" $75 \%$ claimed 24 -hour connectivity, $8 \%$ were on-line for between 1-3 hours and $17 \%$ connected for 5-8 hours.

The question "How long does it take for you to respond to requests/complaints received on-line?" had 34\% stating within 15 days, 34\% saying responses had to come from head office and $8 \%$ would respond within one month. Respondents chose from a list of replies to the question "Do requests received via the internet have to be followed up in writing and if so why?". Their choices are summarised in Table 3 in order of priority.

Table 3

Why Must Requests Submitted via the Internet Be Followed up in Writing?

\begin{tabular}{|l|l|}
\hline Priority & Reason \\
\hline 1 & To be legally confirmed \\
\hline 2 & Due to legal weakness \\
\hline 3 & Impossible to transmit signature electronically \\
\hline 4 & General public's lack of information \\
\hline
\end{tabular}

"Exactly which services can users of the internet (both members of the organisation and the general public) access via your organisation?" produced a range of replies which can be summarised as "documents and reports concerning the organisation, generic public information, the Official Gazette, tender details, legal information, statistics and information relating to the services provided by any one particular organisation".

Respondents were also asked to prioritise from a given list their responses to the next question "In providing services via the internet what benefits did your organisation hope to achieve?" and their choices are tabulated in Table 4.

"In the context of e-government within your organisation what do you think the weaknesses are?" again this question was asked with a given array of responses to be prioritised and results are set out in Table 5. 
Table 4

Expected Benefits From On-Line Public Services in Kars

\begin{tabular}{|l|l|}
\hline Priority & Expected benefit \\
\hline 1 & Transparency of service \\
\hline 2 & Ability to give correct information \\
\hline 3 & Reduction in paper-based operations \\
\hline 4 & Ability to deliver services more quickly \\
\hline 5 & Increase in users' trust in the authority \\
\hline 6 & Rise in speed and ease of decision-making \\
\hline 7 & Establish "trust relationship" between citizens and government \\
\hline 8 & Greater control over payment of bills \\
\hline 9 & Time-saving \\
\hline
\end{tabular}

Table 5

Public Authorities in Kars' Perceived Weaknesses Within E-government

\begin{tabular}{|l|l|}
\hline Priority & Weakness \\
\hline 1 & Insufficient legal framework \\
\hline 2 & Low level of knowledge \\
\hline 3 & Weaknesses within technology \\
\hline 4 & Lack of specialist personnel \\
\hline 5 & Secrecy and lack of trust \\
\hline 6 & Weaknesses in the portal \\
\hline 7 & Network weaknesses \\
\hline 8 & Funding \\
\hline
\end{tabular}

Table 6

Distribution of E-government Password Users by Province Throughout Turkey

\begin{tabular}{|c|c|c|c|c|c|c|c|}
\hline Province & No. & Province & No. & Province & No. & Province & No. \\
\hline 1. İstanbul & $2,143,791$ & 22. Eskişehir & 81,964 & 43. Çorum & 35,859 & 64. Sinop & 18,078 \\
\hline 2. Ankara & 578,197 & 23. Sakarya & 80,632 & 44. Kirklareli & 34,198 & 65. Karabük & 16,986 \\
\hline 3. İzmir & 506,003 & 24. Şanlıurfa & 80,269 & 45. Osmaniye & 31,237 & 66. Artvin & 14,912 \\
\hline 4. Antalya & 308,504 & 25. Ordu & 75,700 & 46. Rize & 31,096 & 67. Bitlis & 14,458 \\
\hline 5. Bursa & 273,240 & 26. Afyon & 71,748 & 47. Adiyaman & 30,608 & 68. Erzincan & 14,370 \\
\hline 6. Konya & 235,687 & 27. Kütahya & 66,074 & 48. Kastamonu & 30,445 & 69. Çankırı & 14,106 \\
\hline 7. Kocaeli & 207,577 & 28. Malatya & 59,951 & 49. Burdur & 30,208 & 70. Kırşehir & 13,996 \\
\hline 8. Adana & 199,946 & 29. Trabzon & 59,815 & 50. Batman & 29,622 & 71. Bingöl & 13,622 \\
\hline 9. Mersin & 178,681 & 30. Zonguldak & 57,597 & 51. Mardin & 29,607 & 72. Bartın & 13,448 \\
\hline 10. Manisa & 162,264 & 31. Sivas & 49,598 & 52. Amasya & 27,040 & 73. Kars & 11,280 \\
\hline 11. Gaziantep & 140,465 & 32. Tokat & 45,423 & 53. Niğde & 25,808 & 74. Şirnak & 10,956 \\
\hline 12. Denizli & 133,611 & 33. Çanakkale & 44,073 & 54. Bolu & 25,030 & 75. Kilis & 7,524 \\
\hline 13. Balıkesir & 131,340 & 34. Elazı̆̆ & 42,601 & 55. Aksaray & 22,344 & 76. Gümüşhane & 7,160 \\
\hline 14. Samsun & 131,047 & 35. Düzce & 41,012 & 56. Karaman & 21,179 & 77. Iğdır & 6,652 \\
\hline 15. Kayseri & 128,440 & 36. Erzurum & 40,942 & 57. Kirıkkale & 19,813 & 78. Ardahan & 4,828 \\
\hline 16. Tekirdağ & 120,497 & 37. Uşak & 40,774 & 58. Siirt & 19,673 & 79. Hakkâri & 4,623 \\
\hline 17. Hatay & 107,130 & 38. Isparta & 39,884 & 59. Nevşehir & 19,278 & 80. Tunceli & 4,156 \\
\hline 18. K.Maraş & 105,552 & 39. Van & 39,821 & 60. Yalova & 19,023 & 81. Bayburt & 3,656 \\
\hline 19. Muğla & 93,426 & 40. Giresun & 37,263 & 61. Ağr1 & 18,875 & & \\
\hline 20. Aydın & 92,294 & 41. Yozgat & 35,951 & 62. Muş & 18,817 & & \\
\hline 21. Diyarbakır & 85,091 & 42. Edirne & 35,898 & 63. Bilecik & 18,360 & & \\
\hline
\end{tabular}

Note. Source: Interview with TURKSAT, May 2011. 


\section{The Other Side of the Coin: Population of Kars Using Pass-Worded E-government, Telephone and Internet Connectivity}

The E-government Gateway project was created to ensure that public services could be delivered electronically, that all citizens could benefit equally from this development and that it would be the sole point of access. Citizens wishing to use the service must obtain an e-government password. Throughout the country the concept of "E-government password" was actively promoted by Turksat and, following an interview with them, they e-mailed the figures below showing numbers of passwords issued to date (Interview/e-mail May 2011).

As it can be seen from the above, Turkey at this point had a total of 7,779,330 e-government users. In Kars, the province where we carried out our research, during the first month that passwords were available, January 2009, a mere 11 people applied for a password. By 2011, in the month of March alone, almost 550 users applied for passwords. In May 2011, as it can be seen from Table 6, the province of Kars had 11,280 registered e-government users and lay 73rd in the ranking of the total 81 provinces.

As for telephone and internet connectivity, in May 2011 Turk Telecom had around 33,200 telephone subscribers in Kars of which 12,137 were also connected to the internet (Interview with Turk Telecom, May 2011).

There had also been a nationwide research project on internet connectivity entitled "Usage of information technology by household" run by the Turkish Statistical Institute (TÜIK) which analysed a random sample of 10,000 homes. Data collected in 2007 showed that $18.4 \%$ were connected to the internet and by 2010 this had risen to $42.8 \%$. Unfortunately this indicates that $57.2 \%$ were still not able to access the internet.

\section{Conclusion and Discussion}

E-government is stated to be the use of information technology by the government's own organisations to deliver their services. Hence for e-government to function, those employed within public services and all the users of those services must be able to understand e-government, and have a sufficient level of skill to make usage practicable. At the same time e-government projects and applications need to be planned, with appropriate feasibility studies undertaken within the public authorities and organisations.

Planning for e-government has to come from the centre. It has been a constructive development that the State Planning Organisation has now been given the job of coordinating "E-Turkey". To gain benefits from e-government applications all organisations should work together in a holistic fashion. The tendency for each body to organise its own working methods internally has to be abandoned. Turk Telecom already delivers services to all of Turkey's seven distinct geographic regions and is thus ideally placed to identify optimum infrastructure. As there has been no central coordination for e-government projects to date, the initiative has already wasted unknown amounts of money. In the overall inventory of Turkish e-government projects the latest arrival is the National Plan for Information (TUENA) (Retrieved from http://www.tuena.tubitak.gov.tr). In the past with different Ministers and heads of public services over 60 projects were established. However, without putting in place the necessary legislation, and solving issues around electronic signatures, forging binding agreements on-line, and data protection all applications come up against the same obstacles (Ozcivelek, 2009).

Some representatives of public service organisations on reading the results of this research have said that it shows the e-government application in Kars was successful, save for the lack of sufficient levels of computer 
technology. At the same time it has to be considered that to upgrade the technology within organisations needs significant investment. At the very least the numbers of computer users, the numbers of computers connected to the internet, and the number of personnel with adequate computer and internet skills needs to increase. Within public bodies there is a need for clear instructions. For example, there is a lack of clear guidelines on the responses to be made to requests/complaints. Clearly in the context of computer usage things cannot continue with so few skilled (trained) personnel: existing personnel must be trained on the service delivery programmes. It would seem that the most important weaknesses in e-government applications, in order, are the lack of an underpinning legal structure, a low level of knowledge amongst both users and personnel employed in public bodies, weaknesses in the technology, lack of specialist personnel, secrecy and a lack of trust, weaknesses in the portal and local networks and funding issues; all of these should be examined as a matter of priority.

In Kars links need to be put in place between web sites of public bodies and those of other interested organisations. In this way it can be said that, within a given time, services will increase from the same website. Whilst this will create benefits for a greater number of users, it is not an ideal application of e-government. This is because one of the basic objectives of e-government is the sharing of work practises and data, and the basic foundation that would achieve this is not yet in place. In fact what has been established in Kars is not a level of e-government but merely a form of e-organisation. One example of this is Kars Municipality where local people still cannot pay their water bills automatically on-line. The web site cannot cope and merely exists to give out information. Another example is the website of Kars Chamber of Manufacture \& Business which has only a home page with no other content. Meanwhile an example from the private sector could be that of an organisation advertising a seminar on-line which, if citizens wish to attend, they go to the website of the company organising the seminar, where they can access forms to be completed on-line and pay the fee for the event via the internet. However, it could be said that it is not a fair comparison with public bodies whose function should be to provide services on the internet.

Despite all the negative aspects of the state of affairs in Kars it is fair to say that there is still a high level of commitment to the development of a service culture in an electronic environment. This is fruitful ground for the development of e-government, especially in Kars which is in a less developed region of the country. However, investment in technology must be made, and the need for more sensitive, quality personnel must be met and training programmes provided for existing personnel.

In the context of benefitting from e-government one of the biggest problems is that the number of users has not reached pre-set targets. As stated above, Kars is in an underdeveloped area of the country where levels of literacy are low, computer and internet usage are similarly below levels in other regions, hence e-government take-up has not reached target. Thus to ensure people can benefit from e-government applications capacity building is necessary, presentations about e-government need to be made with the concept clearly explained to the general public. Otherwise e-government usage will not reach desired levels.

New computer systems are needed to overcome incompatibilities in information and management systems in public authorities, establish secure information transfer within and between these bodies, and increase the work rate (Basar \& Bolukbas, 2010).

E-government aims to deliver public services in a more dynamic fashion whilst ensuring quality. This research will conclude with proposals as to how this may be achieved. 
It is accepted that e-government must take place in a holistic fashion. Different organisations have to be made to work together. They must abandon the practice of working independently with discrete routines. E-government services have to become prevalent, and to achieve a state where all citizens can access and use the services requires greater efforts to be made in the context of encouraging usage. There are some types of web sites which already provide information and are heavily used. These could be replicated and once users realise that necessary services are available from highly functional web sites, the rates of usage should naturally increase. A change has to be made from a situation in which public bodies, of their own volition, have created independent types of e-organisations, to a truly holistic application of e-government. Users need to be made aware by public bodies of the nature of electronic services which can meet their needs and expectations.

Whilst low levels of literacy and income in Kars lead to a need to make e-government services truly transparent and simple to use, along with provision of necessary training on internet usage there is also another difficulty here, not found in the western developed regions of the country. Specifically, the existing old-fashioned entrenched bureaucratic government service in a province such as Kars, means it is difficult to attract new personnel, and to recruit the high quality, skilled personnel necessary to run successful e-government services is an even greater problem. Quality personnel must be encouraged to relocate. This could possibly be achieved by offering information seminars to existing personnel in public service in other regions.

In order to take advantage of e-government services users need a computer and an internet connection. Turkey is one of the most expensive countries for internet usage. The Organisation for Economic Co-operation and Development (OECD) produces statistics on broadband costs which show they range from a low of $\$ 2.39$ to a high of $\$ 76.11$ according to the speed (megabytes/second) and Turkey is amongst the most expensive countries in the OECD's listing (Urhan \& Kizilca, 2011). TÜIK's research referred to previously also shows that to become an internet subscriber in Turkey requires a high initial outlay. There is a clear positive correlation between an individual's level of income and internet usage. For this reason, in low income areas such as Kars, costs for internet usage should be lowered and this would attract more users to e-government services.

It is openly accepted that establishing e-government services in a region such as Kars is far more difficult than doing so in the western areas of the country. For this reason local Adult Education Institutes should offer free courses on computer and internet usage.

It is accepted that the problems in implementing e-government applications would always be greater in lesser developed regions such as Kars, nevertheless the problems are serious. For example it is clear that the critical element in e-government development is user ownership of a computer and internet connection. In 2009 TÜIK carried out research which showed that $62 \%$ of the population of Turkey had never used the internet. The number of households connected to the internet in Turkey was 25\% in 2008, 30\% in 2009 and had risen to $41.6 \%$ by 2010. Despite this apparent increase, it should be noted that in a low income region such as Kars, the figure for internet connections is no doubt lower than that in the developed areas in the west of the country. To overcome this problem internet charges should be lowered in Kars and similar low income regions. More schools should be connected to the internet and local people given access to the schools' computers at weekends.

In Kars, as in all other parts of Turkey, one of the barriers to e-government implementation is resistance to change on the part of public servants. This resistance is to change, to new developments and new technologies 
(E-government Applications, 2003, p. 40) and this can be seen openly in Kars. Public servants need to be informed and educated in e-government.

Internal applications within public bodies are also important. Applications aimed at the general public and external companies have to be based upon internal functionality. Different public bodies are operating on different platforms and with varying understanding of what they are trying to achieve. Overall coordination is needed to untangle and strengthen the current situation. In this context if all public bodies could agree to share the same database there would be a lessening of repetition and a saving in terms of inherent bureaucracy and supplies. At its most basic level the problem is one of sharing information and documentation. To embed a culture of sharing and working holistically is more difficult within the public sector than in the commercial world. In general the public sector disdains sharing skills and knowledge (E-government Applications, 2003, p. 52). It was determined in Kars that any culture of sharing information and working together was extremely weak. A good example of this is the case of a person seeking credit from a government bank, only to be told they must provide proof of identity by making a formal application to the local population directorate. We have seen that e-government applications require personnel with advanced technology skills, in Kars there is a great need for such people. All the public bodies who took part in our research in Kars expressed the need for specialist personnel.

Another proposal in terms of this, from the other side of the coin, concerns the low take-up of e-government services in Kars. As it has been stated in Turkey as a whole there are 7,779,330 holders of passwords for e-government of which a mere 11,280 are in Kars province, thus placing Kars 73rd in the list of 81 provinces. E-government services cannot be accessed without the necessary password and one way to raise the number of users in regions such as Kars would seem to be to waive the cost of the password.

It is proposed to conduct further research under the heading of "E-government password usage" which will examine populations of provinces, level of education, income and so on, and what effect those factors have. Research undertaken by the company Taylor Nelson Sofres (TNS) in 2001 showed that the usage of e-government services at that time was lowest in Turkey with only 3\%, whilst Norway at the other end of the scale had 53\%. In May 2011, the number of telephone subscribers in Kars was around 32,200 of which only 12,137 also had internet connectivity (Interview with Turk Telecom, 2011). Hence it can be seen that only $35 \%$ of possible users of e-government actually have the necessary internet connection and, for electronic services to truly function the usage needs to be much higher. In TUIK's 2010 research entitled "Usage of information technology by household" which looked at 10,000 households across the whole country, $57.2 \%$ were still not connected to the internet (TÜIK, 2010). It is proposed that these numbers will only be raised when the relevant administrations are prepared to address the issues involved, and a transparent way to do so would be to include this topic in the regularly produced bulletins entitled "provincial reports".

Turkey currently lies in a median position in world rankings for e-government. This is because the necessary underpinning legislation has not yet been put in place, legal orders have not been made and public authorities are still weak in terms of shared working practise and data. To overcome the current situation there is a need for widespread use of information technology, for the raising of literacy levels in underdeveloped regions such as Kars, for the introduction of cheaper internet access in such regions, and across the country e-government needs to be promoted and clearly explained with appropriate courses made available so that all citizens can truly become involved. 


\section{References}

Acar, M., \& Kuvas, E. (2008). E-government, e-transformation and integration standarts as an key mechanism on transformation process of Turkey. 2. Congress of National Economics, 20-22 February.

Arifoglu ve Digerleri. (2002). Turkey on way of e-government. Ankara: Association of Turkey Informatics.

Basar, S., \& Bolukbas, A. (2010). Development indicators and e-goverment indexes. Ataturk University Journal of Social Science Institute, 14(1), 157-170.

Basbakanlı. (2009). E-government and knowledge society law draft plan. Retrieved from August 7, 2009, from http://akgul.bilkent.edu.tr/e-devlet/taslak.pdf

Celikkol, O. (2008). E-government construction in public administration and e-government model suggestion for Turkey (Postgraduate Thesis, SD University, Social Science Institute, Isparta/Turkey).

Demirel, D. (2006). E-government and world samples. Journal of Sayıstay, 61, 83-118.

DPT. (2005). E-government project and applications. DPT Department of Knowledge Society, September. Retrieved from http://www.bilgitoplumu.gov.tr

DPT. (2007). OECD e-government studies: Turkey. Undersecretariat of DPT.

Evren, A. (2004). The aims of e-government. Retrieved November 28, 2004, from http://www.bthaber.com

Gocen, A. G. A., \& Şengönül, A. (2011). Interpretation of e-government practices and other e-practices of Turkey and draft of Turkish e-government law. 9. International Conference on Knowledge, Economy and Management Proceedings, 120-128.

Henden, H. B., \& Henden, R. (2005). Changing in service supplying of local government and e-municipality. Journal of Electronic Social Sciences, Fall, 4(14), 48-66.

Ince, N. M. (2001). Electronic government, new possibilities in supplying public services. DPT, May, 2001.

ITO, (2003). E-government applications ve impacts on economics. ITO Publications Number: 2003-38, Istanbul, Turkey.

Moon, M. Jae. (2002). The evolution of e-government among municipalities: Rhetoric or reality? Public Administration Review, 62(4), 424-433.

Ozcivelek, E. (2009). Argument on e-government in world and Turkey: A inquirying on concept. Retrieved from http://www.uzay.tubitak.gov.tr

Sahin, A. (2007). E-municipality applications in turkey and the case of Turkey. Erciyes University, Journal of Faculty of Economics and Administration Sciences, Number, 29, July-December, 161-189.

Uckan, O. (2003). E-government, e-democracy and Turkey, strategy and policies for reconstruction of public management-I, Literatur Publishing, Istanbul, Turkey.

Ulusoy, A., \& Karakurt, B. (2002). Obligation in Turkey's access to e-government. I. Congress of National Knowledge, Economics and Management, Kocaeli University, Publication of Journal of Faculty of Economics and Administration Sciences, Izmit, Turkey.

Urhan, B., \& Kizilca, I. (2011). How is changing persons' internet using in Turkey? TEPAV, Retrieved from http://www.tepav.org.tr

Yildirir, H., \& Karakus, E. (2004). E-government and applications. Retrieved February 11, 2011, from http://www.isguc.org.tr 